\title{
DEVELOPMENT OF A SPECIFIC QUANTITATIVE REAL-TIME PCR ASSAY TO MONITOR CHLORELLA DNA: A CASE STUDY FROM MAMMOTH CAVE NATIONAL PARK, KENTUCKY, USA
}

\author{
RAZVOJ ANALIZNE METODE KVANTITATIVNEGA PCR \\ V REALNEM ČASU, SPECIFIČNEGA ZA MONITORING DNA \\ CHLORELLA: PRIMER IZ NACIONALNEGA PARKA MAMUTSKE \\ JAME, KENTUCKY, ZDA
}

\author{
Richard F. FOWLER ${ }^{1}$
}

\begin{abstract}
UDC 582.263:551.444(736.9)

Richard F. Fowler: Development of a Specific Quantitative Real-Time PCR Assay to Monitor Chlorella DNA: A Case Study from Mammoth Cave National Park, Kentucky, USA

Estimates of phytoplankton abundance are important parameters watched by stewards of water quality and freshwater ecology in rivers, streams, and reservoirs. A targeted phytoplankton assay for Chlorella DNA was developed to estimate the abundance of the predominant species of green algae in surface waters of Mammoth Cave National Park (MACA) in Kentucky, USA. The phytoplankton community in the Green River in MACA has been shown to consist of 95\% Chlorella sp. (Wullschlegger et al., 2003). Chlorella $18 S$ rRNA gene sequences were amplified and quantified using Quantitative Real-Time PCR (qPCR) with primers specific for the family Chlorellaceae in the class Trebouxiophyceae, order Chlorellales. Concentrations of Chlorella DNA in river water samples were measured by comparison to a standard curve generated by DNA extracted from a live laboratory culture of $C$. vulgaris. DNA isolated from other sources including bacteria, amoebae, fungi, decapods, insects, cave sediment, and a different green alga, Chlamydomonas, produced no PCR products and thus did not interfere with the detection and quantification of Chlorella DNA. The assay proved quantitative over more than four orders of magnitude with a method detection limit (MDL) of approximately $2.3 \times 10^{4}$ cells/L. Presence or absence of Chlorella DNA could be demonstrated at concentrations ten to 100 times lower than the calculated MDL. Chlorella was detected in lampenflora samples from three tourist trails, and Chlorella was absent from sediment samples off tourist trails that were known to contain high concentrations of bacterial DNA. Demonstration of the utility of the technique was illustrated by a case study in Mammoth Cave National Park to determine Chlorella concentrations at various sampling sites of karst surface streams where invasive zebra mussels are a threat to native species.
\end{abstract}

Keywords: Chlorella, DNA, qPCR, phytoplankton, resource management, water quality.
Izvleček

UDK 582.263:551.444(736.9)

Richard F. Fowler: Razvoj analizne metode kvantitativnega PCR v realnem času, specifičnega za monitoring DNA Chlorella: primer iz Nacionalnega parka Mamutske jame, Kentucky, ZDA

Ocena abundance fitoplanktona je pomemben parameter, ki ga uporabljamo za ugotavljanje kakovosti voda ter ekologijo sladkih voda kot so reke, potoki in vodni zbiralniki. Ciljna metoda za ugotavljanje DNA alge Chlorella v fitoplanktonu je bila razvita za oceno abundance te prevladujoče vrste zelenih alg v površinskih vodah $\mathrm{v}$ Nacionalnem parku Mamutske jame (MACA), Kentucky, ZDA. Fitoplanktonsko združbo v reki Green River v MACA v kar 95\% dokazano sestavlja alga Chlorella sp. (Wullschlegger et al., 2003). Sekvenca genov 18S rRNA za algo Chlorella je bila specifično pomnožena in kvantificirana s PCR v realnem času (qPCR) s specifičnimi začetnimi oligonukleotidi za družino Chlorellaceae v razredu Trebouxiophyceae, red Chlorellales. Koncentracije DNA alge Chlorella so bile iz vodnih vzorcih reke preračunane glede na standardno krivuljo koncentracij DNA, ki je bila izolirana iz žive laboratorijske kulture $C$. vulgaris. DNA, izolirana iz drugih organizmov vključno iz bakterij, ameb, gliv, decapodov, žuželk, jamskega sedimenta, in druge vrste zelenih alg Chlamydomonas, $\mathrm{v}$ PCR reakciji ni dala speficičnega produkta, kar pomeni, da ni vplivala na specifičnost detekcije in kvantifikacije DNA alge Chlorella.Test je kvantitativen v razponu več kot štirikratnega reda velikosti z mejo detekcije metode (MDL) pri približno 2,3 $\mathrm{x} 10^{4}$ celic/L. Prisotnost ali odsotnost DNA alge Chlorella je bilo mogoče dokazati tudi $\mathrm{v}$ koncentracijah deset do stokrat nižje od izračunane vrednosti MDL. Chlorella je bila detektirana v vzorcih lampenflora vzdolž treh turističnih poti, ne pa tudi v sediment izven turističnih poti, ki je znano, da vsebujejo visoke koncentracije bakterijske DNA. Prikaz uporabnosti te tehnike za ugotavljanje koncentracije alge Chlorella je bil ponazarjen na primeru Nacionalnega parka Mamutske jame na različnih mestih vzorčenja površinskih kraških vodotokov, kjer invazivna školjka potujoča trikotničarka predstavljajo grožnjo za naravno tam prisotne vrste.

Ključne besede: Chlorella, DNA, qPCR, fitoplankton, upravljanje z vodnimi viri, kakovost vode.

\footnotetext{
${ }^{1}$ WATERS Laboratory and Hoffman Environmental Research Institute, Applied Research and Technology Program, Western Kentucky University, Bowling Green, KY 42101 USA; e-mail: richard.f.fowler@gmail.com
}

Received/Prejeto: 25.2.2010 


\section{INTRODUCTION}

Phytoplankton refers to a collective population of autotrophic diatoms and cyanobacteria. By virtue of their capacity for photosynthesis they are an integral part of the freshwater community. Algae are also exotic species introduced into cave environments where lights for tourist trails cause the growth of lampenflora. Phytoplankton use nutrients in the water and sunlight to grow and are the base of the aquatic food web. Estimates of phytoplankton abundance are important parameters watched by stewards of water quality and freshwater ecology in rivers, streams, and reservoirs. In Mammoth Cave National Park the Green River supports a high level of aquatic biodiversity on the surface and in the cave due to backwashing during flood events. Native mussel species in the Green River are being threatened by the exotic zebra mussel (Dreissena polymorpha) which deprives native species of nutrients (Wullschlegger et al. 2003).

Another important issue is the introduction of algal communities in caves where lighting on tourist trails encourages algal growth (lampenflora) on speleothems and cave walls. Not only are these growths a nuisance and undesired consequence of opening caves to tourism, but they introduce exogenous microorganisms in sensitive cave microfloral communities. Much effort is aimed at nondestructive and biologically benign inhibition of growth of lampenflora in tourist caves (Mulec \& Kosi 2009; Smith \& Olson 2007).

Chlorophyll-a is the primary photosynthetic pigment contained in algae. Chlorophyll-a extraction has historically been used to measure algal biomass in water since the 1950's (Creitz \& Richards 1955). Standard Method 10200-I (Marshall 2005) assumes that chlorophyll-a constitutes $1.5 \%$ of the dry weight of algae, thus algal biomass has traditionally been calculated by multiplying the chlorophyll-a content by 67 . Chlorophyll extraction must be carried out in the dark and chlorophylla fluorescence provides an indirect and nonspecific estimate of phytoplankton concentration. This paper describes a targeted qPCR assay to estimate the abundance of the predominant species of green algae in surface waters of Mammoth Cave National Park (MACA) in Kentucky. The phytoplankton community in the Green River in MACA has been shown to consist of 95\% Chlorella sp. in all samples collected from September 2000 through June 2002 (Wullschlegger et al. 2003, p. 22). Thus, Chlorella was chosen as the target genus to monitor phytoplankton in the park.

\section{METHODS}

\section{CULTURE OF CHLORELLA CELLS}

A stock culture of C. vulgaris (Pratt strain, propagated from IUCC398, Indiana University) was obtained from Carolina Biological Supply (Burlington, NC). One liter of HSM medium was inoculated with C. vulgaris in a Fernbach flask and supplemented with $25 \mathrm{ml}$ of filter-sterilized carbonated water once daily (Xia \& Gao 2003) in indirect sunlight during the day (20,000 lux) and under fluorescent light overnight (3000 lux) with gentle agitation. Aliquots $(10 \mathrm{ml})$ of culture were withdrawn every 24 hours for extraction of DNA and enumeration of cells of $5 \mu \mathrm{l}$ aliquots (in triplicate) observed by phase contrast microscopy at $400 \mathrm{x}$ magnification. Growth was also monitored by absorption of visible light at $678 \mathrm{~nm}$ and other wavelengths. The one liter culture was intended to supply a large quantity of $C$. vulgaris DNA for use as a quantitative control during the study, and when harvested on day 12 the saturated culture was divided into four $250 \mathrm{ml}$ portions for DNA extractions.

\section{WATER SAMPLES}

Samples taken from Trammel Fork at the confluence with Middle Fork Drakes Creek (karst area in Warren Co., KY, Barren River Watershed, UTM coordinates 555978 E, $4080882 \mathrm{~N}$ ) in June, 2005 were used to monitor Chlorella in phytoplankton and test the sensitivity of the method in karst surface streams. Volumes of water including 1300, $1000,750,500,250$, and $100 \mathrm{ml}$ were filtered through $0.45 \mu \mathrm{m}$ MCE membranes and environmental DNA was extracted from the filters. Environmental DNA extracts were used as templates in qPCR reactions to measure the concentration of Chlorella DNA in the original samples. Different volumes of water were filtered to determine the minimum volume of sample needed for routine collection and to test the sensitivity of the assay on Chlorella DNA in the environment. Samples of one liter were ideal because the signal was well within range for accurate quantification and filters did not clog with sediments and other particulate material. One liter of water was collected in 11 opaque amber plastic bottles and kept chilled at 


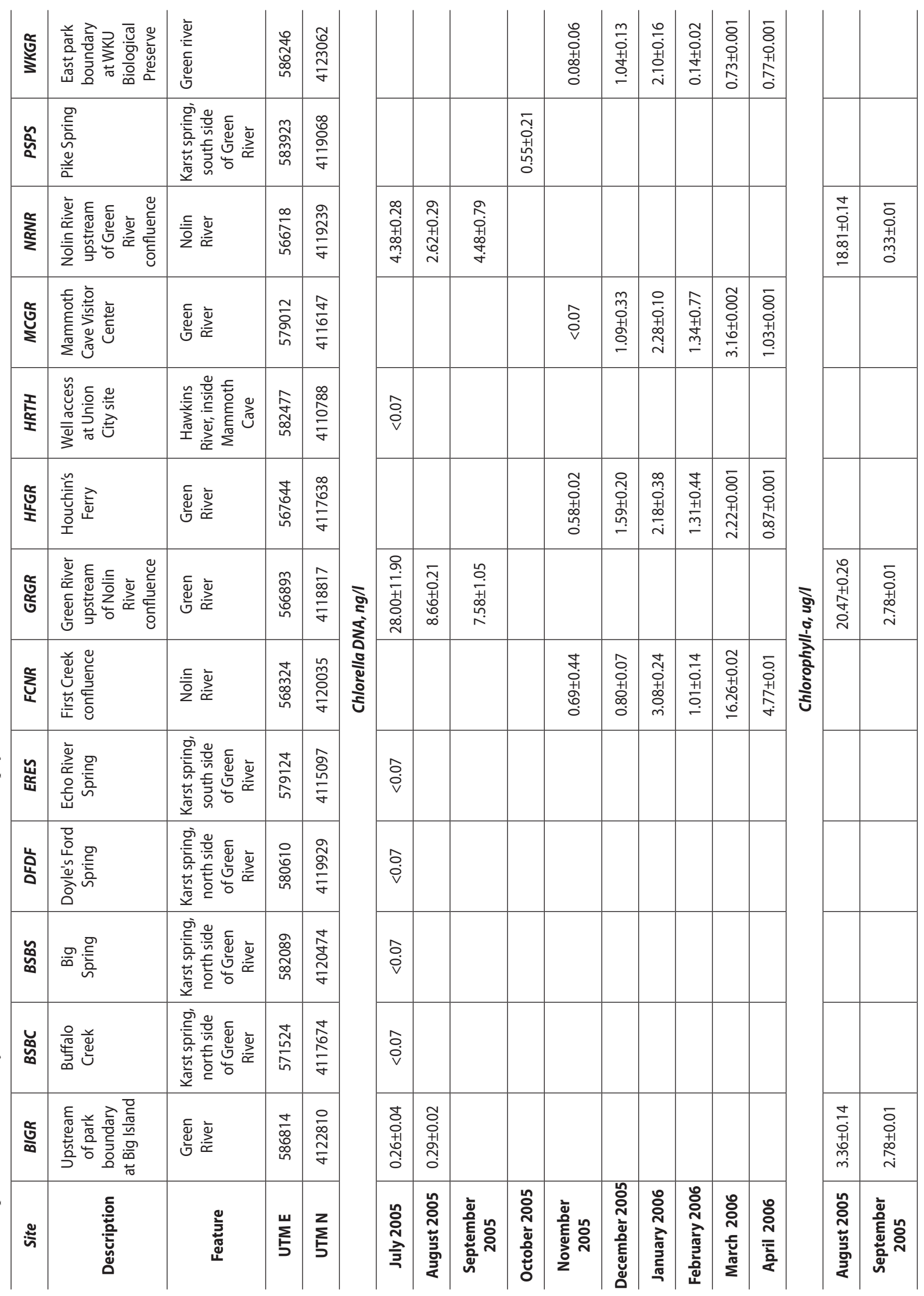




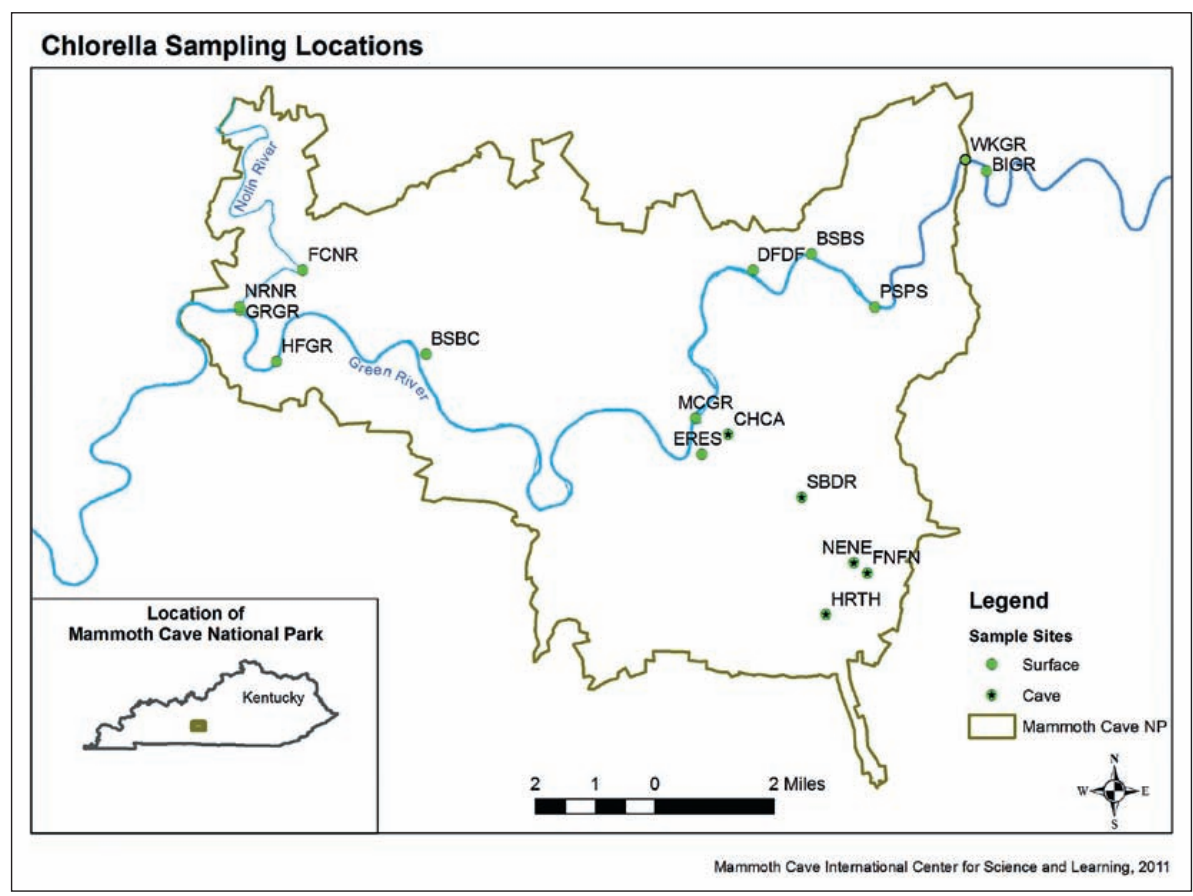

Fig. 1: Map showing sampling sites in Mammoth Cave $\mathrm{Na}$ tional Park. Surface collection sites along the Green and Nolin Rivers are indicated by $\mathrm{O}$, and collection sites for water and lampenflora inside the cave are indicated by $\star$.

pod DNA was isolated from shrimp, insect DNA was isolated from a butterfly, and plant DNA (data not shown) was isolated from clover and wild strawberry collected on the Western Kentucky University campus. Water samples collected in the field and the C. vulgaris culture were passed through $0.45 \mu \mathrm{m}$ cellulose nitrate filters that were frozen until assayed. DNA

$4^{\circ} \mathrm{C}$ until filtered. Mammoth Cave National Park surface stream samples were collected from July 2005 through April 2006 at selected sites along the Green and Nolin Rivers in MACA for DNA analysis (Fig. 1 \& Tab. 1). For the first field trial in July, five samples were taken from springs where subterranean aquifers emerged into the river and fewer photosynthetic organisms would be expected in the vicinity of the discharged volume. DNA was extracted from saturated clastic sediments collected from the pool at the base of a perpetual waterfall at Charon's Cascade (CHCA). The site is away from any lighting or tourist activity in the historic section of Mammoth Cave and DNA extracted from that site was used as a negative control ("cave DNA") due to the inability of green algae to grow in the absence of photosynthesis.

\section{LAMPENFLORA SAMPLES}

Algal growth inside Mammoth Cave was scraped from cave walls near fluorescent lighting along tourist trails at Frozen Niagra (FNFN), New Entrance (NENE), and Snowball Dining Room (SBDR) in September 2010 (Fig. $1 \&$ Tab. 2).

\section{DNA EXTRACTION}

DNA from a variety of organisms was obtained from colleagues or extracted from small amounts of tissue with the UltraClean Soil DNA kit (MOBio Laboratories, Carlsbad, CA, USA). Bacterial DNA was isolated from E. coli, fungal DNA was isolated from a culture of Aspergillus, Deca- was extracted with UltraClean Mega Soil DNA extraction kits (MOBio Laboratories). The manufacturer's protocol was followed including the suggestion of heating at $65^{\circ} \mathrm{C}$ during cell lysis to facilitate rupture of the cellulose walls characteristic of Chlorella. Aliquots of extracted DNA were examined by agarose gel electrophoresis to verify template DNA integrity and yields. For isolation of Chlorella cells for production of a DNA quantification standard, a one liter culture was harvested after two weeks. DNA extracts were eluted with water, freeze dried, and redissolved in $1 \mathrm{ml}$ TE. Concentration of DNA extracts was determined by UV spectrophotmetry. DNA extractions yielded an average of $9.95 \pm 0.33 \mu \mathrm{g}$ of Chlorella genomic DNA from each of four replicate $250 \mathrm{ml}$ aliquots. Cells were counted by phase-contrast microscopy at the end of the growth period as they were during monitoring of the growth of the culture. Environmental samples were quantified only by DNA analysis because the exact strain of Chlorella in those samples was not known, and the presence of numerous planktonic organisms along with association of individual Chlorella cells into multicellular congregates interfered with precise enumeration of Chlorella cells. Indeed, the ultimate goal of this study is aimed at quantification of Chlorella and related species by DNA analysis as an alternative to chlorophyll-a fluorescence or direct microscopic counting of cells.

\section{TOTAL DNA CONCENTRATION MEASUREMENT}

Total DNA concentrations were measured in DNA extracts using the Qubit Fluorometric DNA High Sensitiv- 
Tab. 2: Sites where lampenflora growth was collected near tourist trail lights in Mammoth Cave National Park.

\begin{tabular}{c|c|c|c|c|c}
\hline Site & \multicolumn{2}{|c|}{ FNFN } & \multicolumn{2}{c}{ NENE } & SBDR \\
\hline Description & $\begin{array}{c}\text { Frozen } \\
\text { Niagra } \\
\text { Trail 1 }\end{array}$ & $\begin{array}{c}\text { Frozen } \\
\text { Niagra } \\
\text { Trail 2 }\end{array}$ & $\begin{array}{c}\text { New } \\
\text { Entrance } \\
\text { Trail 1 }\end{array}$ & $\begin{array}{c}\text { New Entrance } \\
\text { Trail 2 }\end{array}$ & $\begin{array}{c}\text { Snowball Dining } \\
\text { Room }\end{array}$ \\
\hline UTM E & \multicolumn{2}{|c|}{583543} & \multicolumn{2}{|c}{583202} & 581766 \\
\hline UTM N & 4111941 & \multicolumn{2}{|c}{4112205} & 4113982 \\
\hline \multicolumn{7}{|c|}{ Chlorella DNA } \\
\hline $\begin{array}{c}\text { Presence of } \\
\text { Chlorella }\end{array}$ & $\sqrt{ }$ & $\sqrt{ }$ & $\sqrt{ }$ & $\sqrt{ }$ & $\sqrt{ }$ \\
\hline
\end{tabular}

ity Quantitation System according to the manufacturer's instructions (Invitrogen, Carlsbad, CA, USA).

\section{QUANTITATIVE REAL-TIME PCR (QPCR)}

Primers specific for the non-transcribed spacer in the nuclear 18S ribosomal RNA gene of the Chlorellaceae family (Class Trebouxiophyceae) of green algae were used to amplify a $195 \mathrm{bp}$ fragment in the presence of the DNA-binding fluorescent dye SYBR Green I (Malinen et al. 2003; Ponchel et al. 2003). Genus Chlorella-specific forward CHspeRmaeF (5'-GGGCCTTTTCAGGTCTGGTA-3') and class Trebouxiophyceae-specific reverse TreSR (5'-GCCAGTGCACACCGAAAC-3') primers (Hoshina \& Imamura 2008; Hoshina et al. 2005) were synthesized by Sigma-Genosys (The Woodlands, TX, USA). All qPCR reactions for unknowns and standards were carried out in triplicate on a Bio-Rad iCycler Real-Time PCR system (Bio-Rad Laboratories, Hercules, CA, USA). DNA templates were amplified in $50 \mu \mathrm{l}$ volumes containing $25 \mu \mathrm{l}$ iQ SYBR Green 2x Master Mix (Bio-Rad Laboratories, Hercules, CA, USA) with 25 picomoles of each primer $(5 \mathrm{ul}$ of $5 \mu \mathrm{M})$. A twostep thermocycling protocol was used for amplification, consisting of an initial melt at $95{ }^{\circ} \mathrm{C}$ for $3 \mathrm{~min}$, followed by 40 cycles of $95^{\circ} \mathrm{C}$ for $10 \mathrm{sec}$. and $60{ }^{\circ} \mathrm{C}$ for $45 \mathrm{sec}$., and a final extension step of $72{ }^{\circ} \mathrm{C}$ for $1 \mathrm{~min}$. The amplification step was followed by melting point analysis from $55^{\circ} \mathrm{C}$ to $95^{\circ} \mathrm{C}$ and agarose gel electrophoresis of an aliquot of the PCR reactions following melting point analysis to demonstrate amplification of a discrete DNA fragment, and aliquots of the PCR reactions after melting point analysis were examined by agarose gel electrophoresis to confirm the length of the amplified fragment.

\section{DNA SEQUENCING}

After PCR the samples were analyzed by agarose gel electrophoresis. DNA was extracted from gel slices containing the $195 \mathrm{bp}$ PCR products using the Ultraclean GelSpin DNA extraction kit (MOBio Laboratories), and purified DNA from gel slices was sequenced with the ABI BigDye Terminator V. 3.1 reagent (Applied Biosystems, Foster City, CA, USA). Primers used for sequencing were CHspeRmaeF (5'-GGGCCTTTTCAGGTCTGGTA-3') and class Trebouxiophyceae-specific reverse TreSR (5'-GCCAGTGCACACCGAAAC-3'), the same as those used to generate the PCR products. Capillary electrophoresis for DNA sequencing was carried out on an ABI 3130 Genetic Analyzer (Applied Biosystems).

\section{RESULTS}

\section{GROWTH AND MONITORING OF CHLORELLA IN CULTURE}

Chlorella vulgaris was grown in the laboratory and monitored by visible spectrophotometry, microscopic counting of cells, and DNA analysis. Daily aliquots $(10 \mathrm{ml})$ were removed from a $1 \mathrm{l}$ culture and filtered. Total DNA extracted from that filter was quantified by spectrofluorometry and compared to the cell density counted under the microscope (Fig. 2).

\section{ESTABLISHMENT OF SPECIFICITY FOR CHLORELLA}

DNA extracted from cultured C. vulgaris cells and purified DNA from a variety of other organisms were amplified under identical conditions in qPCR with primers specific for Chlorellaceae and related species. Gel electrophoresis and DNA sequencing of that product (Fig. 3) proves that it is the $195 \mathrm{bp}$ fragment predicted from known sequences of the $18 \mathrm{~S}$ ribosomal RNA gene of many species of Chlorella and related genera in the GenBank database (searched with BLAST, Altschul et al. 1997). No ampli- 


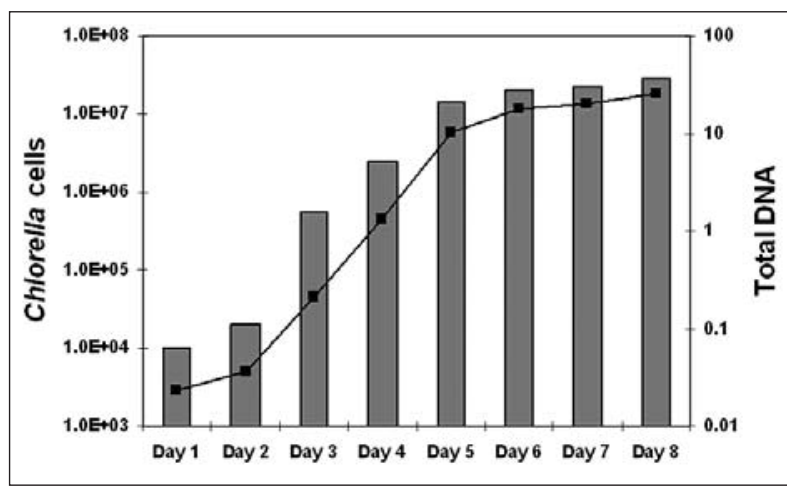

Fig. 2: Growth curves of C. vulgaris culture monitored by counting cells under a microscope (bars) and by determining the total amount of DNA (ng) extracted from daily aliquots ( $\mathbf{a})$.

Site descriptions are in Tab. 1 \& 2.

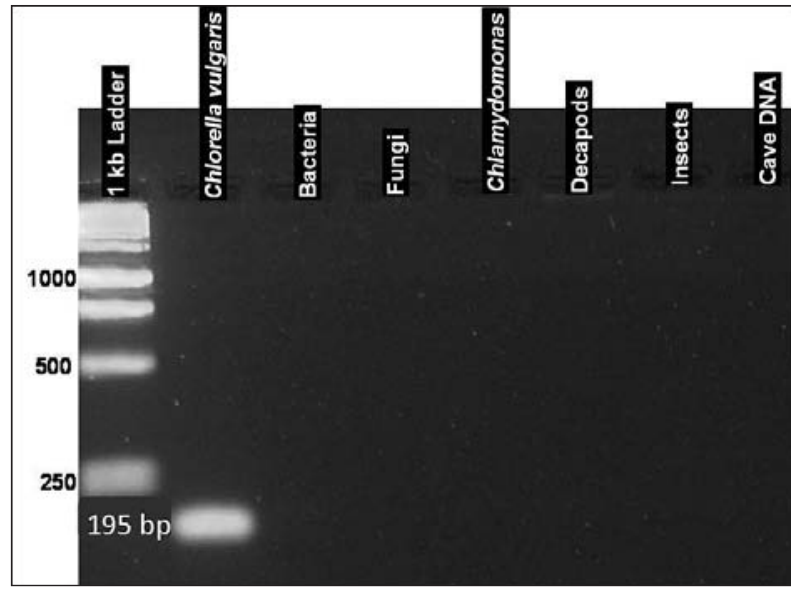

Fig. 3: Agarose gel showing products of qPCR with a fragment with the predicted length of 195 bp amplified only when Chlorella DNA was used as a template, and purified DNA from other organisms or a cave environment did not react in the assay.

fication was seen with DNA extracted from a different genus of green algae, Chlamydomonas (Chlamydomona- daceae), or with a set of DNA samples from tissue samples and cultures of unrelated organisms.

DNA extracted from sediment deposited by a river inside the cave known to contain bacterial, fungal, and proved negative for the presence of Chlorella, a photosynthetic green algae. These data demonstrated that the qPCR assay was specific for the predominant phytoplankton genus in MACA watersheds and the presence of other DNA sequences commonly extracted from environmental sources did not amplify with Chlorella primers. Previous studies confirmed that numerous bacterial and other microbial species were present in the sample, using universal primers for bacteria and fungi (Fowler 2008).

\section{QUANTITATIVE ANALYSIS OF CHLORELLA 18S RDNA}

Standard curves were constructed for each qPCR experiment from known concentrations of genomic DNA isolated from cultures of $C$. vulgaris. Confident replications of triplicates were seen over more than four orders of magnitude of DNA concentration. DNA samples taken from extracts of $10 \mathrm{ml}$ aliquots of a C. vulgaris culture from inoculation through eight days of growth were amplified by qPCR, and their concentrations were determined by comparing $C_{t}$ to that of the standard (Fig. 4). The concentration of DNA measured by qPCR leads to calculation of the total amount of DNA extracted from each $10 \mathrm{ml}$ aliquot of culture. Cultured cells were enumerated by counting cells in small aliquots of the culture under the microscope. A growth curve based on the enumerated cell density closely paralleled that of the same culture based on the amount of Chlorella DNA in the extracts. Chlorella DNA concentrations determined by qPCR were used to calculate the total amount of DNA in the original sample. This value was reported as ng/l of Chlorella genomic DNA.
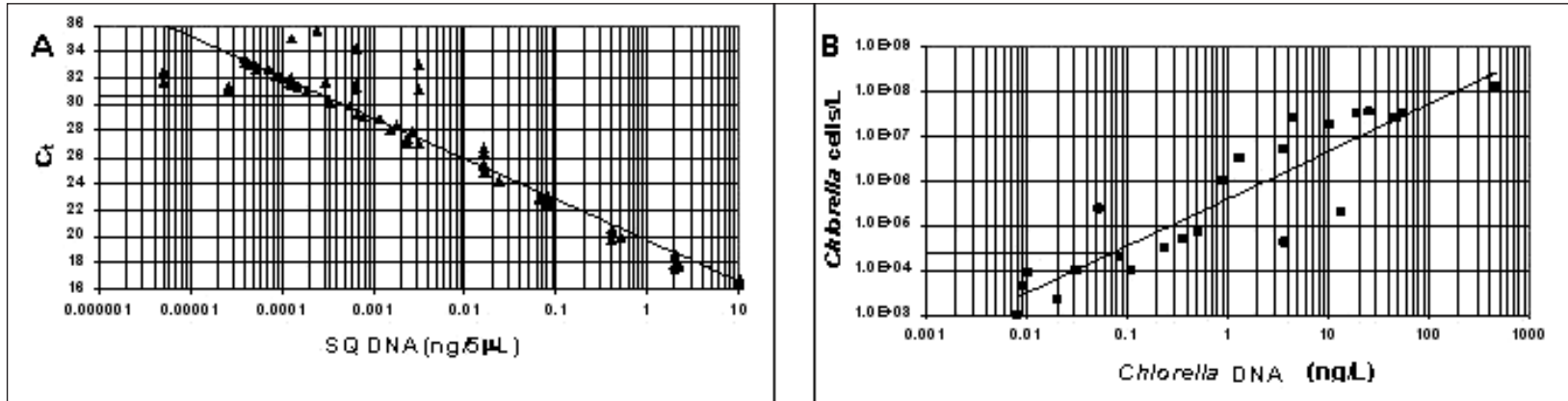

Fig. 4: Graphs of qPCR quantification curves and conversion to cell numbers. (A) Graph of Ct vs SQ for DNA extracted from a culture of $C$. vulgaris used to determine Method Detection Limit (MDL). (B) Graph showing the DNA results from C. vulgaris cultures with cell densities counted under the microscope. The qPCR assay can accurately quantify Chlorella DNA down to the MDL of $0.07 \mathrm{ng} / \mathrm{l}$, corresponding to approximately 23,000 Chlorella cells/l. 


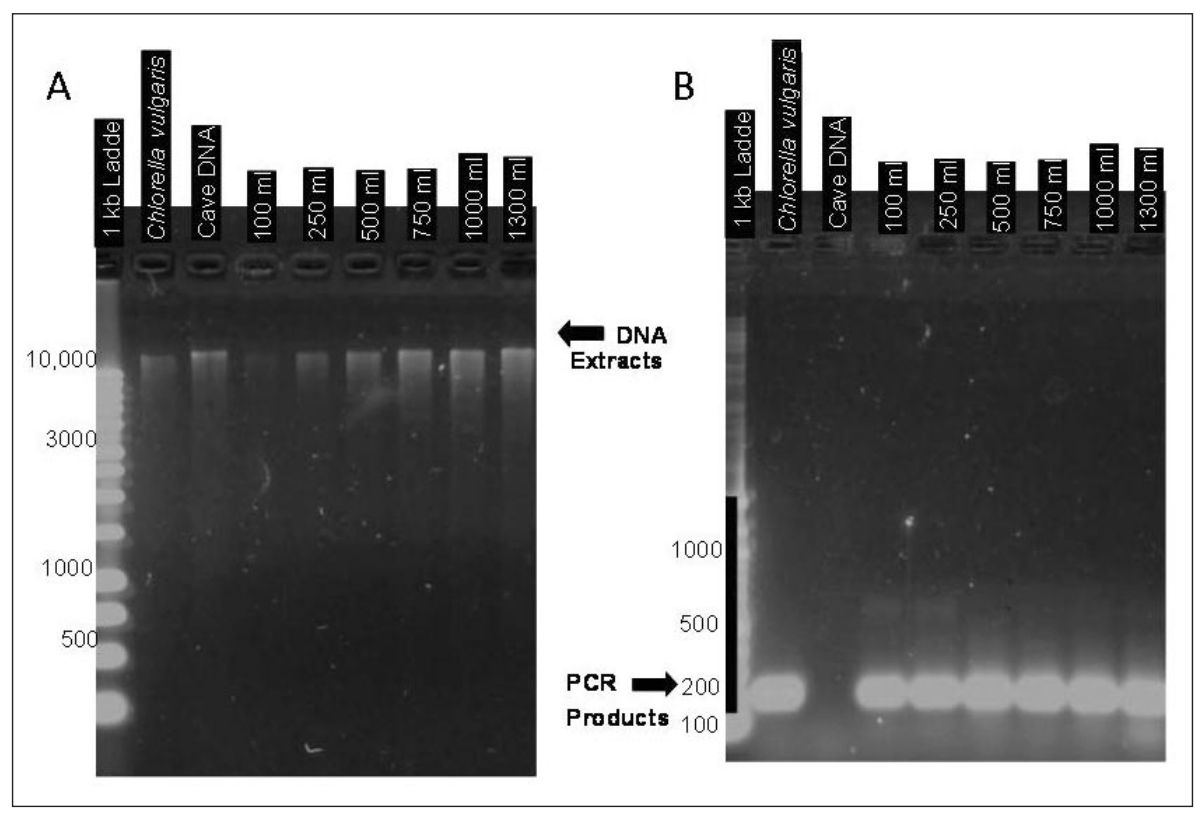

Fig. 5: Agarose gels showing DNA extracts (A) from C. vulgaris (positive control) and cave sediment DNA (negative control) along with environmental DNA extracted from increasing volumes of sample, and (right) the products obtained after $q P C R$ (B). DNA used for PCR amplification was extracted from filters after passage of $100 \mathrm{ml}, 250 \mathrm{ml}$, $500 \mathrm{ml}, 750 \mathrm{ml}, 1000 \mathrm{ml}$, and $1300 \mathrm{ml}$ samples of water from Trammel Fork of Drakes Creek, Warren County, KY.

Positive detection of Chlorella was seen with as little as $100 \mathrm{ml}$ of surface stream sample, and no Chlo-

\section{QUANTITATIVE METHOD DETECTION LIMIT (MDL)}

According to Standard Method 1030-C, MDL is defined as 3.14 times the standard deviation of seven averaged measurements near the minimum detection limit (Eaton et al. 2005; Osborn 2005). Using this definition and our cumulative data the MDL for this assay is $6.9 \mathrm{E}-02 \mathrm{ng} / \mathrm{l}$ Chlorella DNA, equivalent to $2.33 \mathrm{E}+04$ cells/l (Fig. 4). Chlorella DNA was detected, but not accurately quantified, at much lower concentrations.

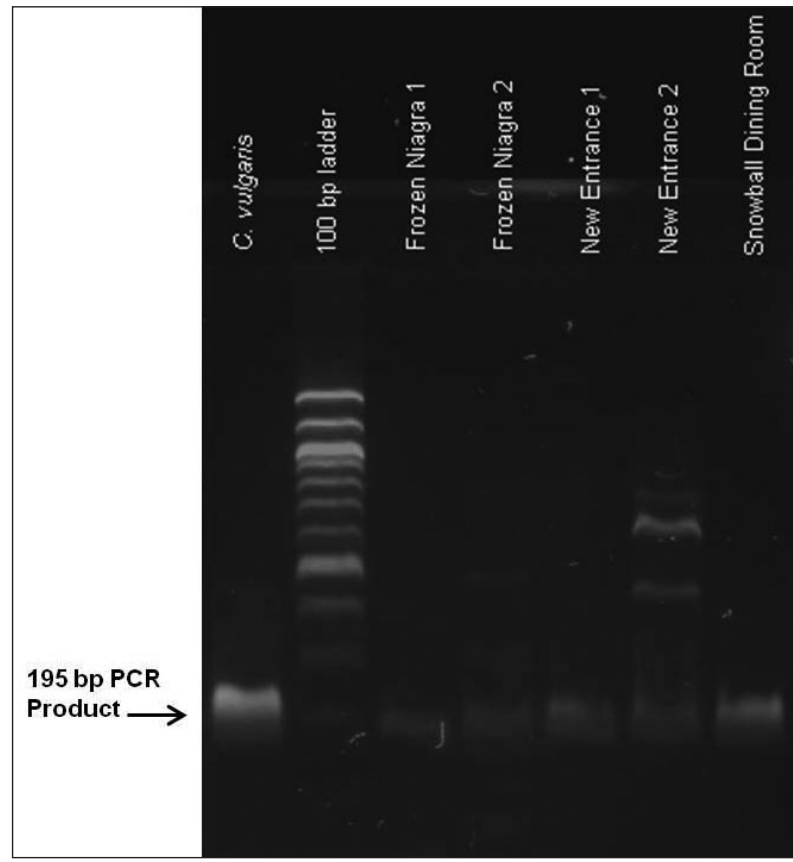

rella DNA was detected in cave sediment DNA (Fig. 5). Parallel measurements were made with chlorophyll-a fluorescence during two sampling periods to show that conclusions from DNA analysis are concurrent with the traditional chlorophyll-a fluorescence measurement. Comparisons of DNA vs. chlorophyll data are included in Tab. 1 for two sampling periods.

\section{APPLICATION OF THE ASSAY FOR MONTHLY MONITORING OF PHYTOPLANKTON IN KARST SURFACE STREAMS}

One liter of water was collected monthly starting in July 2005 at selected sites along the Green and Nolin Rivers in MACA for DNA analysis. For the first field trial in July, five samples were taken from springs where subterranean aquifers emerged into the river and few photosynthetic organisms would be expected in the vicinity of the discharged volume. Sampling continued at key study sites from November, 2005 until April, 2006. Water samples were filtered and DNA was extracted from the filters. Aliquots of the environmental DNA extract ( $5 \mu \mathrm{l}$ out of $1000 \mu \mathrm{l})$ were used as templates in qPCR to determine concentrations of Chlorella DNA in the extracts. The total amount of Chlorella DNA extracted from one liter

Fig. 6: Agarose gel showing Chlorella PCR products from lampenflora collected from Mammoth Cave tourist trails. Frozen Niagra (FNFN), New Entrance (NENE), and Snowball Dining Room (SBDR) all showed detectable levels of Chlorella $D N A$, as shown by the presence of the 195 bp PCR product and partial DNA sequences of gel bands. 
samples of river water was calculated from the concentrations $(\mathrm{ng} / 5 \mu \mathrm{l})$ and volumes $(1000 \mu \mathrm{l})$ of the extracts. The concentrations of Chlorella DNA in ng/l are summarized in Tab. 1.

\section{DETECTION OF CHLORELLA DNA IN LAMPENFLORA}

DNA extracted from scrapings of green growth near cave trail lights at Frozen Niagra (FNFN), New Entrance
(NENE), and Snowball Dining Room (SBDR) proved positive for detection of Chlorella. Gel electrophoresis of PCR products showed the $195 \mathrm{bp}$ band like that seen in C. vulgaris cultures (Fig. 6). PCR products were isolated from agarose gel slices and short DNA sequences (approximately $100-150 \mathrm{bp}$ ) of those bands matched Chlorella and closely related genera.

\section{CONCLUSIONS}

Previous studies showed that $95 \%$ of the phytoplankton in surface streams at MACA was Chlorella, DNA concentration in extracts from environmental samples is measured by qPCR by comparison to a standard curve generated by purified DNA isolated from cultured Chlorella cells. The purified DNA used as a standard was extracted from a large amount of culture thus yielding a concentrated DNA extract whose concentration was measured by scanning UV-Vis spectrophotometry and fluorometry. Thus, DNA concentrations are based on physical and chemical constants characteristic of the ultraviolet absorption spectrum of DNA and fluorescence of intercalating dyes. For this reason, results are expressed as ng/l, of Chlorella DNA. Results expressed as number of cells is an estimate based on multiple microscopic examinations and is subject to change as the data is refined, whereas the DNA concentration is a fixed result that can be converted to cell numbers at a later time.

Cumulative results in which the number of cells in culture aliquots was counted under a microscope was plotted against the total amount of DNA measured in the samples allowed estimation of the number of cells/l represented by the DNA concentration in ng/l. Roughly, 1 ng/l of Chlorella genomic DNA corresponds to 400,000 Chlorella cells/l.

Error in this conversion lies in the counting of cells in very small aliquots $(5-10 \mu \mathrm{l})$ under the microscope and factoring by 1000 to the original sample volume (10 $\mathrm{ml}$ ), not in the determination of DNA concentration.

The results demonstrate that phytoplankton are less abundant along the Green River where subterranean springs discharge into the main river channel, and minor fluctuations in phytoplankton concentration were seen along the Green River over the study period. A spike in chlorella concentration in March 2006 at FCNR on the Nolin River (Tab. 1) corresponded to a release from the Nolin River Dam, apparently discharging higher algae concentrations from the reservoir. It follows that more phytoplankton could support a larger population of native and invasive mussel species in the Nolin River and in the reservoir behind the dam. Park scientists should pay close attention to the Nolin River tributary due to the higher potential for invasive mussels.

Detection of Chlorella DNA in lampenflora means Chlorella can be used as a convenient cultured organism to study algal growth along illuminated tourist trails in caves. Results were obtained in two working days and the cost of the test was comparable to fluorescent determination of chlorophyll-a concentration by spectrofluorometry. In our hands, qPCR was more convenient to carry out and many samples were analyzed simultaneously. Moreover, this test proved specific for a particular species determined to be representative of the phytoplankton community as a whole in MACA. The assay can be used to specifically monitor other species or higher taxa by use of the appropriate primer pair in the QPCR reaction. For any given species to be monitored a quantity of purified DNA from the target organism must be isolated and its concentration determined by UV-Vis spectroscopy or fluorometry in order to generate a standard curve for that particular species assay. 


\section{ACKNOWLEDGMENTS}

This work was commissioned and funded through a cooperative agreement with Mammoth Cave National Park (MACA). All work at Mammoth Cave National Park was supervised by Rick Olson, Mark DePoy, or Bob Ward of Science and Resources management at MACA. Dr. Rick Toomey of the Mammoth Cave International Center for Science and Learning prepared the map of sample sites.
DNA samples from butterfly (order Lepidoptera) were obtained from Dr. Jeff Marcus and Chlamydomonas from Dr. Sigrid Jacobshagen. Acknowledgements go to Christal Wade for technical expertise in the laboratory and to Jonathan Oglesby for assistance in preparation of the manuscript.

\section{REFERENCES}

Altschul, S.F., Madden, T.L., Schæffer, A.A., Zhang, J., Zhang, Z., Miller, W. \& D.J. Lipman, 1997: Gapped BLAST and PSI-BLAST: a new generation of protein database search programs.- Nucleic Acids Research, 25, 3389-3402.

Creitz, G.I. \& F.A. Richards, 1955: The estimation and characterization of plankton populations by pigment analysis. III. A note on the use of 'Millipore' membrane filters on the estimation of plankton pigments.- Journal of Marine Research, 14, 3, 211 216.

Fowler, R., 2008: Final Report to the National Cave and Karst Research Institute, National Park Service, USA. [Online] Available from: http://people.wku. edu/rick.fowler/mammoth/progress.html [Accessed?]

Hoshina, R. \& N. Imamura, 2008: Eu-Chlorella large subunit rDNA sequences and group I introns in ribosomal DNA of the paramecian symbiotic alga NC64A.- Phycological Research, 56, 21-32.

Hoshina, R, Kato, Y. Kamako S., \& N. Imamura, 2005: Genetic Evidence of "American" and "European" Type Symbiotic Algae of Paramecium bursaria Ehrenberg.- Plant Biology 7 ,5, 526-532.

Malinen, E., Kassinen A., Rinttila, T., \& A. Palva, 2003: Comparison of real-time PCR with SYBR Green I or 5'-nuclease assays and dot-blot hybridization with rDNA-targeted oligonucleotide probes in quantification of selected faecal bacteria.- Microbiology, 149, 269-277.

Marshall, H.G., 2005: Biological Examination, Plankton, Determination of Biomass.- In: Eaton, A.D., Clesceri, L.S., Rice, E.W., \& A.E. Greenberg (eds.) Standard Methods for the Examination of Water and Wastewater, $21^{\text {st }}$ Edition, American Public Health Association, 10, p. 26.
Mulec, J. \& G. Kosi, 2009: Lampenflora algae and methods of growth control.- Journal of Cave and Karst Studies, 71, 2, 109-115.

Osborn, K.E., 2005: Introduction, Data Quality, Method Detection Level.- In: Eaton, A.D., Clesceri, L.S., Rice, E.W. \& A.E. Greenberg (eds.) Standard Methods for the Examination of Water and Wastewater, $21^{\text {st }}$ Edition, American Public Health Association, 1, pp. 17-18.

Ponchel, F., Toomes, C., Bransfield, K., Leong, F.T., Douglas, S.H., Field, S.L., Bell, S.M., Combaret, V., Puisieux, A., Mighell, A.J., Robinson, P.A., Inglehearn, C.F., Isaacs, J.D. \& A.F. Markham, 2003: Real-time PCR based on SYBR-Green I fluorescence: An alternative to the TaqMan assay for a relative quantification of gene rearrangements, gene amplifications and micro gene deletions.- BMC Biotechnology, 3, 18, (13 pp.). [Online] Available from: http://www. biomedcentral.com/1472-6750/3/18.

Smith, T. and R. Olson, 2007: A Taxonomic Survey of Lamp Flora (Algae and Cyanobacteria) in Electrically Lit Passages within Mammoth Cave National Park, Kentucky.-International Journal of Speleology 36, 2, 105-114.

Sueoka, N., 1960: Mitotic replication of deoxyribonucleic acid in Chlamydomonas reinhardii.- Proceedings of the National Academy of Sciences, USA, 46, 83-91. Available from: http://www.pnas.org/cgi/reprint/46/1/83 [Accessed?]. 
Wullschlegger, J., Wilson, J.L., Laughlin, J. \& R. Olson, 2003: Survey of Plankton in the Green River at Mammoth Cave National Park.- Water Resources Division, National Park Service, U.S. Department of the Interior, Washington, D.C., USA, Report number: NPS/NRWRD/NRR-04/01, pp. 20-22. [Online] Available from: http://www.nature.nps.gov/water/annual_reports/NPS_WRD_ AnnualReport2003_5FINAL.pdf [Accessed?]
Xia, J., \& K. Gao, 2003: Effects of doubled atmospheric $\mathrm{CO}_{2}$ concentrations on the photosynthesis and growth of Chlorella pyrenoidosa cultured at various levels of light.- Fisheries Science, 69, 767-771. 